\title{
SIGNOS MÁGICOS Y DE LO ABSOLUTO: APROXIMACIÓN A TÉRMINOS Y CONCEPTOS DE FILOSOFÍA DEL LENGUAJE EN TRES CUENTOS DE JORGE LUIS BORGES ${ }^{1}$
}

\author{
Alberto Rivas Casasayas \\ Universidad Pompeu Fabra
}

En el conjunto de la obra de Jorge Luis Borges es frecuente la aparición de temas y conceptos de índole filosófica. En este trabajo propongo una aproximación interpretativa a tres de sus relatos breves $(E l$ espejo de tinta, La escritura del dios y La Biblioteca de Babel) en función de las implicaciones de filosofía del lenguaje que de ellos se deri-

1 En este trabajo se muestran algunos resultados de los estudios de su autor acerca de la relación entre pensamiento filosofico y la obra de Jorge Luis Borges. Si las consideraciones aquí presentes mereciesen comentario o crítica de cualquier tipo, el autor agradecería que fuesen dirigidas a alguna de estas dos direcciones de correo electrónico: albertoribas@hotmail.com / msxmen@lix.intercom.es

Quisiera, asimismo, expresar mi agradecimiento a Montserrat Bordes Solanas, profesora titular de Filosofía del Lenguaje y de Historia de las Ideas en la Universidad Pompeu Fabra de Barcelona, por el interés que ha mostrado en este trabajo y por la guía que me ha ofrecido, sin la cual éste no habría podido ser llevado adelante. 
van. Si bien es cierto que no son éstas las únicas piezas en las que aparece este tipo de implicaciones, y tampoco es en ellas donde la reflexión sobre el lenguaje es más explícita en comparación con otras obras de Borges, bien merece la pena dedicarles algunas líneas para ver cómo en estos cuentos se reproducen ciertos motivos temáticos característicos de la obra borgeana.

Así, intentaré mostrar que en El espejo de tinta y La escritura del dios se hallan presentes ciertas ideas sobre magia en la comunicación sígnica. Son ideas que, obviamente, no hallan lugar en una discusión filosófica «seria», pero en el caso que nos ocupa fundamentan la trama de ficción. Por ello pretendo exponer en qué consisten estas ideas y cómo se desarrollan a través de dicha trama.

Más característica aún de la obra de Borges es la aparición en sus relatos de un objeto con valor de absoluto. Tal es el caso de $L a$ escritura del dios y La Biblioteca de Babel, donde los personajes narradores explican su camino intelectivo en pos de este «absoluto» que tiene una obvia relación de identidad con la totalidad del universo, bien se trate de una sentencia divina que modifique sus destinos, o bien un libro que lo explique (y lo justifique) en su conjunto. En este trabajo intentaré explicar en qué consiste esa cualidad de «absoluto» que se otorga al objeto buscado en tanto que conjunto sígnico.

No es mi intención hacer un comentario exclusivamente filosófico de estos cuentos, en el sentido de tomar algunas partes de la narración para extraerlas de su contexto (como parte de una obra de ficción, como texto de autor, como producción cultural...) y convertirlas en situaciones ideales aptas para la aplicación en ellas de conceptos filosóficos. Esta suerte de experimento controlado sería más propio de la filosofía pura. Pero tampoco me parece apropiado el comentario de textos como los que aquí se refieren de acuerdo con los cánones de la ortodoxia formalista. Es cierto que, como objeto estético, es indispensable para la comprensión de toda obra literaria su estudio formal, estilístico, retórico... Ahora bien, en la medida en que para expresar sus contenidos el texto literario se sirve de elementos propios de o presentes en otras ramas del conocimiento o la expresión humana (como podrían ser, además de la filosofía, la matemática, la ética, las artes plásticas...), ya sea de una forma explícita o más subyacente, considero apropiada una aproximación hermenéutica mediante conceptos teóricos y métodos propios de esos otros campos. 
En este sentido, creo que la abstracción conceptual y la «literaturización» de la filosofía presentes en la obra de Borges justifican este tipo de aproximaciones. Entiéndase: no se trata de comentar a Borges como a un fíósofo. Si bien es innegable la presencia explícita de elementos de pensamiento filosófico en la obra de Borges (bien apropiados de otros autores, bien como emisiones de juicio por parte del yo narrativo), hay que tener en cuenta que ello no implica necesariamente que la intención del autor sea la de emitir proposiciones filosóficas; en sus escritos, Borges no es ningún filósofo, y menos todavía presenta sistema alguno de creencias, por lo menos en lo que respecta a su obra de ficción. Puesto que aquí se trata de un autor literario, esto que digo parece una obviedad, pero después de examinar parte de la obra crítica al respecto y ver que en ella «pensamiento borgeano» es una expresión asaz empleada en un sentido filosófico, muchas veces sin conocimiento de causa, parece necesario señalarlo. Lo único que Borges emprende como autor de ficción es una literaturización de la filosofía (como hace también con la historia sin que por ello nadie diga de Borges que era un historiador) o la fundamentación en la filosofía de los contenidos narrados en algunas de sus ficciones.

Teniendo esto en mente, podemos permanecer en el campo de la interpretación literaria, aun sirviéndonos de las herramientas conceptuales al uso en otros campos del conocimiento, y sin confundir la naturaleza del objeto de estudio: un texto literario.

El espejo de tinta es una historia que, leída desde una perspectiva ética, explica cómo, a través de un ritual mágico de comunicación sígnica, un personaje se encuentra con sus propias acciones, y cómo éstas se convierten en la síntesis de su destino último. La escritura del dios narra el progreso intelectivo (y el camino moral que de él se deriva) de Tzinacán, un sacerdote azteca en busca de una fórmula sagrada (una «sentencia divina») que repare los males que contra su civilización y su cultura religiosa ha cometido el conquistador español Pedro de Alvarado. Ambos cuentos comparten denominadores comunes: la exposición de ideas sobre la magia del lenguaje, por un lado, $\mathrm{y}$, por otro, la búsqueda de un conjunto sígnico con valor absoluto. 
«Le pedí que nombrara la figura que deseaba mirar. Pensó y me dijo que un caballo salvaje, el más hermoso que pastara en los prados que bordean el desierto. Miró y vio el campo verde y tranquilo y después un caballo que se acercaba, ágil como un leopardo, con una estrella blanca en la frente. Me pidio una tropilla de caballos tan perfectos como el primero y vio en el horizonte una larga nube de polvo y luego la tropilla» (El espejo de tinta, HUI, 126-127) ${ }^{2}$.

El centro del ritual mágico que se muestra en la narración es la tinta. Con ella se escriben las invocaciones y las palabras sagradas que son el prolegómeno del encantamiento, y ello se puede entroncar con una visión mágica del lenguaje. Las palabras mágicas hacen cosas, crean un encantamiento, son vehículo de una invocación. Según una perspectiva mágica del lenguaje, determinadas palabras no son un mero símbolo, esto es, un elemento abstracto al que una comunidad otorga un significado de acuerdo con la normativa convencional del código que sus miembros emplean, sino entidades sustanciales que, descubiertas o ya conocidas por el hechicero, permiten hacer ciertas cosas una vez que son pronunciadas. Dicho de otro modo, la palabra tiene una potencialidad sustancial en sí misma, tiene un poder causal: de su pronunciación (acompañada con frecuencia de un aparato ritual, como sucede en el cuento) se derivan unos efectos materiales palpables. La concepción mágica del lenguaje tiene una relación con el lenguaje divino: «Hágase $\mathrm{X} », \mathrm{y} X$ se produce; las palabras tienen en sí la sustancia misma de aquello que designan, y si la sentencia emitida por el mago o la divinidad enuncia una acción, ésta se realiza en virtud de que la acción se encuentra en estado potencial en la palabra que la designa. La palabra mágica, en suma, es una entelequia ${ }^{3}$ : si la sustancia de la acción, de la cosa, se encuentra en la palabra que le da nombre, entonces la acción, la cosa, se actualizan una vez que la palabra es pronunciada.

A la luz de esto, veamos cuál es el proceso mágico del ritual tal como se expone en la narración. Su objeto esencial, la tinta, tiene un valor de soporte sígnico cuyo objeto es el de mostrar imágenes. Ello se

2 Citaré las fuentes primarias de este trabajo en el cuerpo de texto según este código: HUI, Historia universal de la infamia; A, El Aleph; F, Ficciones. Todas las referencias de página de estos libros corresponden a las ediciones españolas de AlianzaEmecé.

3 Entiéndase «entelequia» en el sentido aristotélico (no en el más coloquial de «cosa imaginada pero no existente»), como entidad inmaterial que contiene en sí misma el motor que conduce al fin o actualización que ella misma es en potencia. Véase Aristóteles (1990: 1074 ${ }^{\mathrm{a}} 36$; 634-635). 
consigue mediante un proceso de invocación ritual después del cual se nombra al objeto que se desea ver, y entonces puede verse su imagen. La tinta es el elemento constitutivo, el componente sustancial del espejo como soporte para la presentación de conjuntos de imágenes con un valor sígnico y que dan pie a un juicio estético, según se extrae del pasaje aquí citado, donde abundan el adjetivo y la comparación y se pide una imagen superlativa, perfecta (el caballo salvaje) ${ }^{4}$. En cuanto a la cualidad sígnica de la secuencia de imágenes, es palpable en la asociación del caballo al leopardo, parangonables en una idea de agilidad, y en el valor simbólico de la estrella, que designa a los caballos como algo extramundano ${ }^{5}$.

Así pues, en el espejo se manifiestan imágenes con un valor sígnico. En cierta manera, puede decirse de ellas que son iconos, puesto que, con la excepción de la última imagen que ve Yakub (la ejecución de su propia persona), todo lo que se muestra en el espejo son «apariencias», como Abderrahmen afirma constantemente en su narración. Ahora bien, generalmente se entiende que toda apariencia, o icono, o representación, tiene entre sus características la de la múltiple interpretabilidad en tanto que es el receptor quien, una vez percibido el signo, le da significado (lo descodifica) en función del bagaje conceptual (o «enciclopedia») que tiene en su mente. Pero por la narración de Abderrahmen podría suponerse que estas imágenes son unívocas, es decir, que tienen una única interpretación. Así por lo menos en el caso de la última imagen, que tiene un estatuto ontológico «superior» al de las imágenes anteriores, de la cual se deriva una única consecuencia en el mundo empírico, correlativa a lo que se muestra en la imagen: la muerte de Yakub. El espejo de tinta es un instrumento de comunicación en tanto que emite imágenes que son signos sensibles de las vagas ideas que Yakub tiene al efectuar sus

\footnotetext{
4 Aunque no una imagen definitiva, ni absoluta, puesto que el objeto deviene luego plural. La solicitud de Yakub concierne a la perfección estética. De las posteriores enumeraciones de las visiones de Yakub puede extraerse que este personaje fluctúa entre el deleite estético y el ansia de conocimiento. En el campo de lo estético Yakub no encuentra nada que de por sí sea único en su género. Tales objetos pueden multiplicarse produciendo el mismo efecto: deleite estético. La naturaleza de lo absoluto en Borges, veremos, va más allá de la mera estética: entra en el campo de lo cognoscitivo. Cuando adquiere la vision de «cosas imposibles de describir», «la ciudad que se llama Europa», al entablar un contacto perceptivo con lo que otros sudaneses del siglo XIX no podrán ver jamás, entonces se entromete en las visiones esa figura del Enmascarado, esa trampa del hechicero que instigará el ansia de Yakub por saber: el deseo de conocer la identidad de la figura descubriéndola.

5 De forma semejante ocurre con la figura del Enmascarado, que se tratará más adelante.
} 
peticiones. Cuando Yakub formula estas peticiones no tiene ninguna idea de lo que va a ver, la expresión de los signos sensibles en el espejo y el significado de éstos no corre a cargo de Yakub, sino del hechicero. De esta manera, no se están expresando signos arbitrarios, sino dirigidos unívocamente desde la mente del hechicero a la percepción del tirano a través del canal comunicativo del espejo. La comunicación, entonces, viene a ser dirigida: Abderrahmen da en el espejo la expresión formal de su propia idea (verbalizada en la categórica expresión «deleites del verdugo y del cruel») sobre la petición expresada por Yakub (como «un inapelable y justo castigo»), y el tirano la percibe de esta manera, sin ninguna libertad interpretativa. El efecto de la imagen en Yakub se basa sólo en la intencionalidad del hechicero. En esta intencionalidad rectora radica el valor mágico de los signos del espejo ${ }^{6}$.

Los únicos objetos que aparecen en el espejo que tienen un carácter de realidad empírica son tan sólo el primero y el último que Yakub ve: su propia persona ${ }^{7}$. Yakub es el hechizado: como imagen, su ser pasa a formar parte del espejo, y por eso el tirano encuentra su supremo instante cuando es ejecutado como imagen. Yakub cae en la trampa que le tiende el hechicero por su avidez de imágenes cada vez más absolutas. Tras la caprichosa enumeración de imágenes (HUI, 127-128) que parecen un tanteo, una comprobación de si se puede ver de todo en el espejo, nos cuenta Abderrahmen que el tirano pronto llega a ver «cosas imposibles de describir», cosas «más complejas» (HUI, 128). Es decir, que en su avidez, Yakub sobrepasa la capacidad lingüística. Más allá de lo imposible de describir (como el alumbrado de gas para un sudanés del siglo XIX) ${ }^{8}$, más allá de su deleite tanático (imágenes «com-

6 En este sentido, puede decirse que el contenido de las proferencias de Yakub es en realidad secundario, aunque, irónicamente, se le muestre al tirano todo lo que desea.

7 «Le pregunté si percibía con claridad su reflejo en el círculo y respondió que sí. Le dije que no alzara los ojos. Encendí el benjuí y el cilantro y quemé las invocaciones en el brasero» (HUT, 126); «Entonces ordené que desnudaran al condenado y que lo sujetaran sobre la estirada piel de becerro y que le arrancaran la máscara. Esas cosas se hicieron. Los espantados ojos de Yakub pudieron ver por fin esa cara - que era la suya propia. Se cubrí de miedo y locura» (HUI, 129).

8 En cuanto a las «cosas imposibles de describir», esta expresión nos conduce a un equívoco. Desde luego, en el momento en que aparecen en el espejo, estas cosas serán imaginables y concebibles, en el sentido de que se crea una imagen que se interpreta perfectamente. Es decir, que del comentario de Abderrahmen, «deleites del verdugo y del cruel», se deduce que se ha interpretado una imagen que es perceptible $y$ reconocible en el horizonte de expectativas mentales del receptor. No es preciso tomarse en su sentido estricto «cosas imposibles de describir», sino entenderlo como el uso de la desgastada hipérbole romántica de la indescriptibilidad. 
plejas» $y$ «atroces»), Yakub va efectuando una escalada hacia lo absoluto e inapelable: su propia muerte.

Parece que Yakub llega a pisar terreno sagrado a pesar de la (inductora) advertencia de Abderrahmen. En el espejo entra un curioso signo: el Enmascarado. Es preciso señalar la plurivalencia del valor iconográfico de la imagen de lo cubierto: la infamia (tema general del libro al que pertenece esta narración), lo sagrado (son abundantes en la iconografía religiosa los velos sobre objetos sagrados, como el paño de Verónica que enjugó la faz de Cristo, o aquellos que no deben ser vistos para no incurrir en sacrilegio), la justicia (en la tradición occidental, una dama con los ojos vendados), o el propio ajusticiado, todos ellos con una significación en el cuento. Nótese que estas son las interpretaciones posibles por parte del lector del cuento. Porque, por lo menos para Yakub, el significado de la imagen del Enmascarado es incomprensible, como se desprende del hecho de que el tirano quiera desvelar esta figura. Ahora bien, es cierto que hay una intencionalidad del hechicero en la emisión de ese signo, y que existen en él unos contenidos que se actualizan en el mundo empírico a partir del momento en que Yakub ordena al hechicero que desvele a la figura.

El espejo de tinta es un mundo de imágenes icónicas que discurre paralelamente al mundo empírico, y está dirigido por la voluntad de un individuo que pertenece a este último. $Y$ en última instancia el mundo sígnico irrumpe en el real con consecuencias que van más allá del deleite estético. La interacción de actos sígnicos entre un mundo y otro acarrea consecuencias para el empírico. Yakub jura, y por este acto enunciativo se responsabiliza de lo que le pueda suceder por desenmascarar a la figura que va a ser ajusticiada. Del texto se desprende que Yakub está llegando a algo definitivo..., y muere como testimonio de su propia vergüienza o por incurrir en sacrilegio, léase como se quiera, pero el hecho es que Yakub muere porque su avidez de imágenes llega al deseo de ver realizado algo absoluto, definitivo, como lo sería, de acuerdo con el horizonte de expectativas de un tirano como Yakub, «un inapelable y justo castigo» (HUI, 129) que, irónicamente, resulta ser el suyo.

Hasta aquí he expuesto una posible forma de entender una buena parte de los contenidos de El espejo de tinta a la luz de algunos conceptos e ideas de filosofía del lenguaje. Creo que este tipo de aproximación es lícita en tanto que es indudable la centralidad del concepto de signo en el cuento y que, haciendo abstracción de sus contenidos, 
en él se narran los pasos de un proceso comunicativo ${ }^{9}$. Lo dicho hasta aquí podría extenderse mucho más, aunque ello llevaría a una interpretación más general, y es el propósito de este trabajo restringirse, en la medida de lo posible, a una perspectiva concreta. Pero, aun así, quisiera apuntar brevemente, sólo para mostrar que la línea de aproximación a la obra literaria de Borges que aquí se sigue no es banal, una posibilidad interpretativa de esta narración fundamentada sobre el campo conceptual aquí esbozado.

En primer lugar, de todos los elementos sígnicos que aparecen en la narración se deriva un efecto. Así, de las invocaciones del Corán, el encantamiento; de las apariencias en el espejo, el deleite estético o tanatofílico; y del juramento de Yakub y el desenmascaramiento de la enigmática figura del espejo, la muerte del tirano. Especialmente en el primero y el último de estos casos, esta causalidad va ligada a una concepción mágica del lenguaje: de la pronunciación de unas determinadas palabras se deriva, inevitablemente, un único efecto posible. Sea la tinta, si se quiere, el vehículo de un tropo (según la acepción retórica, no filosófica) de la propia creación literaria. En ese sentido, la relación pragmática, de marco referencial compartido, entre los conceptos de «tinta»y «escritura» me parece indiscutible. Yakub observa, se deleita, conoce un mundo a través de ese pequeño círculo en la palma de su mano. En esta narración se expondría, entonces, una metáfora de la literatura como creadora de imágenes con un significado. Asociar las imágenes del espejo a la creación en artes visuales me parece demasiado sencillo, en primer lugar porque las imágenes del espejo están dotadas de una movilidad interna que sería poco corriente en las artes plásticas, mientras que en el texto literario sí existe, a nivel conceptual, una actividad interna desvelada en función de la actividad receptiva del lector. Entender el ritual del espejo como correlato de la creación literaria permitiría considerar El espejo de tinta un ejemplo de la frecuente autorreflexividad de la literatura del siglo XX, tan propia también de la creación borgeana.

El fenómeno creativo-comunicativo que en el cuento se narra aparece, en todo caso, vivamente romantizado al dotársele de un carácter taumatúrgico. La comunicación sígnica, como ya se ha dicho antes, es unívoca, viene dirigida por el hechicero-creador-poeta, que va llevando al tirano hacia su destino último. El arte irrumpe en la realidad no

9 No un proceso comunicativo corriente, claro está, sino como producto de un ritual mágico que fundamenta la intriga de la narración. 
sólo en un sentido profético, como sería la manera más propiamente romántica ${ }^{10}$, sino como elemento configurador de la realidad. Mediante esta interacción dirigida entre el mundo empírico de Yakub y Abderrahmen y el mundo de las apariencias, el hechicero consigue sus propósitos: salva su vida, acaba con el tirano y hace justicia.

Estos motivos de raíz romántica no faltan, de hecho, en la literatura del presente siglo ${ }^{11}$. Pero en el caso particular de «El espejo de tinta», la comunicación literaria va más allá de lo puramente estético. Va hacia la teleología: un proceso con una finalidad en sí, dirigido, de alguna manera, por una voluntad trascendente ( un hechicero entre dos mundos?), que lleva todo el proceso hacia una última finalidad suprema. Por su carácter mágico, la virtualidad del mundo de las apariencias irrumpe en el mundo empírico, incide en él y lo modifica: arte configurador de realidades 12 .

De igual manera, y como hemos dicho antes, La escritura del dios tiene un denominador común con El espejo de tinta y La Biblioteca de Babel en lo que se refiere a la búsqueda de un conjunto sígnico de valor absoluto. Si el lector de La escritura del dios quiere tener las palabras de Tzinacán por verdaderas y no desea entenderlas como los delirios de un prisionero enloquecido que de su tragedia pretende hacer su total autorrealización, entonces veamos cómo comienza el camino intelectivo que sigue el personaje:

\begin{abstract}
«QQué tipo de sentencia (me pregunté) construirá una mente absoluta? Consideré que aún en los lenguajes humanos no hay proposición que no implique el universo entero; decir el tigre es decir los tigres que lo engendraron, los ciervos y tortugas que devoró, el pasto de que se alimentaron los ciervos, la tierra que fue madre del pasto, el cielo que dio luz a la tierra. Consideré que en el lenguaje de un dios toda la palabra enunciaría esa infinita concatenación de los hechos, y no de un modo implícito, sino explícito, y no de un modo progresivo, sino inmediato. Con el tiempo, la noción de una sentencia divina parecióme pueril o blasfematoria. Un dios,
\end{abstract}

10 Bastante habitual, al menos, en la literatura romántica. Así, por ejemplo, el episodio de la mina en Enrique de Ofterdingen, de Novalis, de obvias resonancias virgilianas, donde el joven protagonista halla un libro escrito en provenzal que es un compendio de sus hechos futuros como trovador.

11 Particularmente célebre es el final de Cien años de soledad, donde el último Buendía lee, poco antes de morir, el final de la historia de su familia en el libro de Melquíades, un episodio que, a su vez, remite más o menos directamente a «El hundimiento de la casa Usher», de Poe.

12 Esta irrupción de la virtualidad en lo empírico se produce también en «Tlön, Uqbar, Orbis Tertius», una irrupción tan atroz como para conquistar nuestro universo mental, tan banal como para que el receptor de los contenidos de la enciclopedia virtual comprenda que éstos no resisten a su propia ilógica. 
reflexioné, sólo debe decir una palabra y esa palabra la plenitud. Ninguna voz articulada por él puede ser inferior al universo o menos que la suma del tiempo. Sombras o simulacros de esa voz que equivale a un lenguaje y a cuanto puede comprender un lenguaje son las ambiciosas y pobres voces humanas, todo, mundo universo» $(\mathrm{A}, 120-121)$.

Al igual que en La Biblioteca de Babel, en La escritura del dios, a la felicidad por la conciencia de un objeto con valor absoluto que puede ser encontrado se sigue el vértigo por la necesidad de hallarlo dentro de un ámbito de búsqueda tan amplio como el universo (F, 9496; A, 118-119). El sacerdote termina por deducir dónde está escrito ese signo absoluto: en la piel del jaguar, «uno de los atributos del dios» (A, 119). Así, las manchas de la piel del jaguar son un conjunto críptico del que se podrá deducir la sentencia mágica. Ante la probable imposibilidad de descifrar ese criptograma, Tzinacán pasa a preguntarse sobre las características y el sentido de la sentencia pronunciada por la mente absoluta.

Según Tzinacán, de la expresión-recepción de un signo se deriva en sí una cognición causal, en el sentido de que se dice algo y en ese decir están no sólo el elemento actualizado «el tigre», sino también todo el entramado de cadenas causales que le anteceden. De manera que en el concepto se incluye una metafísica de vastas proporciones: el concepto derivado del signo, cuando se piensa, compele necesariamente al pensador a una elucidación de causas en un movimiento regresivo que llega hasta el pensamiento de la idea del origen del Universo. De manera que se entiende que lo designante de ese objeto del mundo empírico designa implícitamente a todo aquello que le precede en la cadena causal. Tales son las implicaciones de las palabras de Tzinacán, expresadas en términos analíticos. Sin embargo, esta regresión producida por el uso del lenguaje humano sólo se lleva a cabo por voluntad del pensador del concepto. Digamos que no se produciría en la experiencia empírica de un hablante común, dado que esta regresión ab initio a partir del concepto expresado en el signo haría de todo punto imposible la comunicación. Pero, en la ficción de Borges, nuevamente los signos están dotados de una virtualidad mágica consistente en la relación causal entre el signo y la realidad empírica del concepto expresado por él. Y esta magia adquiere, de forma aún más notable que en El espejo de tinta un carácter teleológico. Para Tzinacán, este movimiento causal se encuentra explícita e inmediatamente en el signo divino, es decir, que en ese signo (del que, lógicamente, Tzinacán llega a considerar que acaso sea una única palabra) están la realización del 
universo y de su tiempo. La sentencia divina, entonces, sería la identidad del universo, de todo el ser y el transcurrir ${ }^{13}$.

Ahora bien, ¿qué ocurre si el signo es idéntico con lo significado? Un signo no es exhaustivo ni completo en su significado. Es más, necesariamente ha de ser distinto de aquello que representa. $\mathrm{Si}$, como es este el caso, el signo representa algo, no puede ser idéntico a la cosa ${ }^{14}$. Al ser la sentencia formulada en un lenguaje de signos, cabe suponer que el signo buscado por Tzinacán es un signo que, por convención ${ }^{15}$, y no de manera natural, se refiere a una cosa (al universo). La identidad aducida por Tzinacán no puede ser total, porque entonces el signo sería completamente inútil en cuanto a su función referencial. Lo que sucede es que el sacerdote, en sus argumentos, está refiriéndose al signo en lo que respecta a las consecuencias de su empleo, y no a su función referencial. La sentencia divina es un signo divino, mágico, y no tiene un mero carácter de representación convencional, sino que tiene un poder causal ${ }^{16}$. Así, para Tzinacán, «enunciar la infinita concatenación de hechos de manera explícita $e$ inmediata» (el subrayado es mío) se refiere no a una representación más o menos efectiva del universo, sino al extremo de entrometerse en el manejo de sus leyes causales y temporales y en el cambio de sus

13 Tal como se expresa en las palabras de Tzinacán, esa sentencia vendría a ser algo parecido a la causa causarum aristotélica. Nuevamente se trata de una entelequia (vid. supra, n. 3). Notese por otra parte la semejanza de esta idea de la sentencia divina con el pensamiento cristiano: «En el principio era el Verbo, y el Verbo estaba en Dios, y el Verbo era Dios. Él estaba en el principio en Dios. Por él fueron hechas todas las cosas; y sin él no se ha hecho cosa alguna de cuantas han sido hechas» (Juan, 1: 1-3) o «La fe es la que nos enseña que el mundo todo fue hecho por la palabra de Dios; y que, de invisible que era, fue hecho visible» (Hebreos, 11: 3). Es decir, que la palabra divina es el principio esencial de la divinidad y a la vez el medio por el que Dios realiza su voluntad creadora.

Al respecto de la sentencia divina como identidad del mundo, nótese la semejanza temática con La Biblioteca de Babel, donde el llamado «libro total» viene a ser un resumen o compendio del universo. En uno y otro caso, la sentencia divina y el libro total vienen a ser una suerte de conjuros para la existencia absurda de unos personajes.

14 El propio Borges (inspirándose directamente en las fantasías lógicas de Carroll) trata este tema en su brevísimo cuento-ensayo Del rigor en la ciencia (143-4).

15 Otra cuestión es cómo puede la divinidad haber convenido consigo misma la función representativa de su sentencia, pero esto nos llevaría a una escalada en temas metafísicos y teológicos fuera de lugar en este comentario. En lo que respecta a la analítica, esta cuestión podría llevarnos a discurrir sobre las tesis del lenguaje privado (Wittgenstein) si este trabajo se circunscribiese dentro del ámbito del pensamiento puro.

${ }_{16}$ De aquí el riguroso aserto «Sombras o simulacros...» al final del fragmento citado en el cuerpo de texto. «Las ambiciosas y pobres voces humanas todo, mundo universo» se limitarían a una mera función referencial de enorme «pobreza» en comparación con el potencial existente en la sentencia divina. 
sucesos (de acuerdo con las intenciones que declara Tzinacán al principio de su narración).

En fin, parece que el sacerdote se considera incapaz, como humano, de una comprensión del enigma que se ha planteado. El idealismo metafísico de Tzinacán se estrella contra este absoluto intuido cuya esencia está más allá de toda elucidación criptográfica, más allá de toda comprensión lingüística por parte de un intelecto humano (porque el lenguaje divino resulta ser trascendente). Acaso en este pensamiento está la autoaniquilación del pensamiento y el lenguaje de Tzinacán, porque, ¿hay alguna comprensión de lo absoluto en esta reflexión que se lleva a cabo? Acaso sea incomprensible para el pensamiento analítico que intenta apoderarse de él. Acaso el procedimiento analítico de Tzinacán le lleva a una «comprensión negativa», en tanto que asume lo incomprensible. De esta manera, asumiendo su imperfección humana, el sacerdote aniquila su propio pensamiento en un acto de lealtad al dios, asumiendo su imperfección humana y, en consecuencia, autoanulándose intelectivamente, interrumpiendo la escalada hacia el pensamiento absoluto y dejando así al dios lo que, como absoluto y trascendente, sólo a él le atañe.

Lo que se sigue después de esto, puede ser la pérdida del juicio de Tzinacán, o la entrada en él de la divinidad tras este necesario vaciado de sí mismo. En cualquier caso, Tzinacán considera que llega al conocimiento de su sentencia y alcanza un estado de beatitud total, perdida toda su voluntad autoconsciente como sujeto:

\begin{abstract}
«Es una formula de catorce palabras casuales (que parecen casuales) y me bastaría decirla en voz alta para ser todopoderoso. Me bastaría decirla para abolir esta cárcel de piedra, para que el día entrara en mi noche, para ser joven, para ser inmortal, para que el tigre destrozara a Alvarado, para sumir el santo cuchillo en pechos españoles, para reconstruir la pirámide, para reconstruir el imperio. Cuarenta sílabas, catorce palabras y yo, Tzinacán, regiría las tierras que rigió Moctezuma. Pero yo sé que nunca diré esas palabras, porque ya no me acuerdo de Tzinacán.

Que muera conmigo el misterio que está escrito en los tigres. Quien ha entrevisto el universo, quien ha entrevisto los ardientes designios del universo, no puede pensar en un hombre, en sus triviales desdichas o desventuras, aunque ese hombre sea él. Ese hombre ha sido él y ahora no le importa». (A, 123).
\end{abstract}

Nótese, por otra parte, que el final del discurso de Tzinacán resulta un tanto falaz. Según su narración, la visión mística de la rueda [que recuerda a algunos mitos conocidos: la visión de Ezequiel (Ezequiel, 
1: 4-28) o la Bavacakra («Rueda de la Vida») hindú (revela al sacerdote el sentido de la escritura. Es decir, que llega a conocer la sentencia mágica. Su pronunciación haría a Tzinacán (y esto siempre según Tzinacán) todopoderoso; esto está relativamente de acuerdo con sus razonamientos anteriores. Pero la confesión de la certeza de estar en posesión de este poder se expresa mediante argumentos un tanto «religiosos», es decir, verdades relativas que sólo predican para el converso. Dicho de otra manera: su enunciado está relativizado contra el horizonte ideológico del receptor. Tzinacán parece consciente de hallarse en relación dialéctica con alguien, acaso con él mismo. Pero la no realización de los poderes que afirma tener reduce su discurso a mera retórica religiosa. Es decir, que para creer en lo que dice Tzinacán el receptor debería efectuar un acto de fe a partir de sus creencias. En todo caso, cabe insistir: el enunciado es relativo al horizonte ideológico del receptor. Y, si Tzinacán es el propio receptor de su argumento, entonces su soledad se muestra con mayor énfasis: Tzinacán está sólo con sus creencias, y la verdad de su enunciado oscila en la cuerda floja ${ }^{17}$.

Esta sería una posible interpretación del relato, que acaso podría hacerse más exhaustiva en base a un estudio de retórica argumentativa. Pero también se pueden extraer otras consideraciones al respecto del ambiguo discurso del sacerdote, una aproximación de tipo más filosófico que religioso y retórico, empleando conceptos propios de la epistemología y la filosofía analítica.

El camino intelectivo del sacerdote parte de la introspección en la propia memoria. Allí encuentra el recuerdo de la tradición de la sentencia mágica. A partir del recuerdo de sus características, el sacerdote inicia una progresión analítica en busca de dónde puede estar esa escritura de acuerdo con esas características establecidas a priori por la tradición del dios. Los instrumentos intelectivos de los que se sirve el sacerdote son la memoria y el análisis. Ahora bien, ante la piel del jaguar, el sacerdote se halla ante un texto indescifrable. Hasta ese momento, Tzinacán ha estado trabajando en el campo de lo fenoménico: recuerdos, realidades palpables... Hasta que se encuentra ante unas manchas en la piel de un jaguar cuyo significado hay que descubrir. Al entender que las manchas del jaguar son un signo o, mejor, un conjunto críptico, con un significado, de cuya pronunciación se espera además un portentoso efecto, éstas adquieren así una trascendencia.

17 Respecto a esta posibilidad interpretativa, véase también PÉREZ (1986, 159-163). 
Desposeído de la clave mística para elucidar su significado, Tzinacán pasa del ámbito de lo fenoménico al de lo nouménico ${ }^{18}$. Por emplear el vocabulario kantiano, Tzinacán pasa de lo cognoscible a lo metafísico. Podemos conocer, según Kant (1996: 55-57), lo que se da en la experiencia sensible (fenómeno) y pensar lo que está más allá (noúmeno). No parece, según Kant (1996:B823-7), que sea posible adquirir un conocimiento seguro más allá de los juicios sintéticos a priori radicados en las categorizaciones humanas sobre la experiencia sensible; las propias palabras del filósofo son bastante ilustrativas de la angustiosa situación de Tzinacán:

«La razón es arrastrada por una tendencia de su naturaleza a rebasar su uso empírico y a aventurarse en un uso puro, mediante simples ideas, más allá de los últimos límites de todo conocimiento, a la vez que a no encontrar reposo mientras no haya completado su curso en un todo sistemático y subsistente por sí mismo» (Kant, 1996: 625).

Según las cuales Tzinacán sería una trágica víctima de la tensión entre las pobres capacidades humanas y las elevadas aspiraciones de su naturaleza. Sucede que Tzinacán proyecta sobre la piel del jaguar la noción de la existencia de un signo. Ahora bien, la configuración de las manchas del jaguar es demasiado compleja tanto para las capacidades memorísticas de Tzinacán como para las analíticas. Y esto es lo importante: Tzinacán carece de código, de una clave que, innata o adquirida, sea la base para la comprensión del signo mediante el análisis de la configuración de las manchas.

Esto nos lleva a la distinción wittgensteniana del decir-mostrar. Para Wittgenstein, sólo es conocimiento auténtico lo que se puede decir, la expresión de lo pensable. Todo lo que yo pueda pensar o conocer lo puedo expresar en el lenguaje. Pero hay cosas que sólo se pueden mostrar, esto es, ideas de aquello que está más allá de lo decible: el ámbito de lo metafísico como absurdo, área del no-conocimiento aparte de lo cognoscible y, por tanto, enunciable en función de un código lingüístico (Wittgenstein, 1995: 142-3).

Este bien podría ser el proceso por el cual Tzinacán adquiere conciencia de la inelucidabilidad del texto en la piel del jaguar, que él tan sólo puede ver, esto es, sólo se le puede mostrar, sin que el sacerdote

18 Nouménico por lo menos para Tzinacán, a partir de sus preconcepciones. 
sea ni siquiera capaz de albergar esos contenidos en su memoria. Así, el signo no puede ser descifrado en función de las facultades humanas de razonamiento de Tzinacán. Éste precisará de una experiencia mística para hallar lo que busca. Adentrado en un laberinto de sueños, le es mostrada al sacerdote una visión concentrada del universo, y llega al conocimiento de la sentencia. No podía ser sino mediante esta experiencia místico-onírica. «Lo inexpresable, ciertamente, existe. Se muestra, es lo místico» (Wittgenstein, 1995: 6.522). El lector no puede saber cómo le es comunicado este conocimiento a Tzinacán ${ }^{19}$, pero puede aceptar que esta experiencia extramundana comunica el sentido del críptico a Tzinacán, y lo acepta en tanto que anteriormente se ha mostrado que no se podía llegar a este conocimiento por procedimientos de razonamiento analítico.

La negativa de Tzinacán a pronunciar la sentencia podrá entenderse así en el marco temático del silencio como requerimiento místico-filosófico. En qué medida se desprende del texto que un conocimiento absoluto superior lleva a Tzinacán a una conciencia despojada de toda preocupación humana y mundana, arrojando tras de sí la escalera por la que ha subido para permanecer en una suerte de beatitud trascendental, es algo que concierne ya más a la mística o la teología.

II

La misma búsqueda de un conjunto sígnico de valor absoluto se halla también presente en La Biblioteca de Babel ${ }^{20}$ : ese conjunto sígnico al que constantemente alude el narrador es el «libro total» o «catálogo de catálogos». El cuento del matemático y escritor alemán Kurd Lasswitz La Biblioteca Universal, donde se expone la idea de producir libros mediante combinaciones tipográficas, inspiró directa-

19 Es frecuente en la obra de Borges el evitar la narración de los procesos por los que se llega a un hecho fundamental de la trama. Es una licencia que permite el pacto ficcional: no buscar en los hechos una explicación histórica, causal (cómo se ha llegado a esto), sino centrarse en el hecho mismo (qué sucede con esto, qué podemos pensar o esperar de esto). Así, por ejemplo, en «Pierre Menard, autor del Quijote», donde el autor evita la narración del proceso por el que se llega a una obra fragmentaria textualmente idéntica a otros fragmentos del Quijote de Cervantes.

20 En esta sección me veo obligado a prescindir de citas extensas en el cuerpo de texto, más que nada por economía de espacio, dado que las citas que me parecen relevantes para un comentario de esta narración en términos de filosofía del lenguaje abarcan prácticamente la mitad de la narración. 
mente el ensayo de Borges La Biblioteca Total, al que Borges dará una expresión literaria en el cuento que aquí se trata, pero con un añadido original: la asimilación de esta biblioteca a la idea de un universo entero compuesto por libros cuyos habitantes (los bibliotecarios) manifiestan la creencia en un libro (un conjunto de signos único) cuyo contenido es el fundamento explicativo del universo en el que estos personajes se mueven. Aunque existe un enlace temático con los dos cuentos tratados anteriormente, aquí ya no se trata tan sólo de una búsqueda, sino también de la discusión acerca de la posibilidad de la existencia de ese objeto buscado.

La Biblioteca de Babel es un universo de signos lingüísticos repartidos por un espacio que parece infinito, un mundo con sus pensadores del mundo, un mundo con sus ideales absolutos como el catálogo de catálogos, el libro cíclico (una elegante metáfora del hermetismo, a mi parecer). El mundo, la Biblioteca, se compone básicamente de signos, combinados de diferente manera en cada libro. De acuerdo con las indicaciones iniciales del narrador-pensador, son veinticinco signos combinados de diferente manera en cada libro, que contiene cada uno (portadas aparte) 1.312.000 signos (ochenta letras por renglón, cuarenta renglones por página, 410 páginas por libro), de manera que el total de libros se podría calcular según la fórmula $\mathrm{VR}_{25}{ }^{1.312 .000}$, una variación con repetición cuyo resultado parece tendente al infinito. El narrador nos comunica la conclusión a la que han llegado otros bibliotecarios (y que él comparte) de que ésta es una de las claves ontológicas de la Biblioteca: cabe entenderla como un sistema de combinación de signos $(F, 92-94)$.

Se expone otro principio esencial: «los inventores de la escritura imitaron los veinticinco símbolos naturales» (F, 92). La proposición expresada por el bibliotecario-narrador es, cuanto menos, atrevida. Que los signos lingüísticos sean entendidos como símbolos, esto es, elementos que tienen una significación convencional para una colectividad determinada, parece más o menos una categorización propia de la semiología más elemental. Digamos que un signo natural es aquel cuya relación con lo significado es «fruto espontáneo de la manera de ser y comportarse de los objetos, sin intervención ni mediación de convenciones ni reglas interpretativas» (Hierro S. Pescador, 1989: 33), y a los signos naturales los definimos por oposición a los culturales, esto es, aquellos signos cuyo significado se define de acuerdo con unas reglas de comunicación lingüística o de comportamiento establecidas o impuestas en el seno de un colectivo social de forma más o menos 
explícita. Así, el atavío negro del príncipe Hamlet es un signo cultural (no verbal) del dolor por la muerte de su padre, y cuando se le recrimina su persistencia en el luto, también vienen a significar lo mismo sus palabras de respuesta ${ }^{21}$, una respuesta expresada esta vez mediante signos culturales verbales. En cambio, por el llanto de Hamlet se entendería un signo natural, una reacción corporal propia de la naturaleza humana que un testimonio interpretaría como indicio natural del dolor.

De los ejemplos aquí expuestos, parece que se puede extraer la noción de que la mayoría de símbolos son únicamente culturales, no naturales. Ahora bien, es cierto que entre las numerosas formas existentes de comunicación animal (natural, instintiva) se emplean signos que no tienen con lo significado una relación indéxica (indicios) ni imaginativa (iconos), esto es, se trata de puros símbolos. Puede mencionarse aquí el socorrido ejemplo de la danza de las abejas, o bien el caso de cierto tipo de mono africano que emite distintos tipos de gritos de alarma que comunican el tipo de depredador que se acerca, sin que haya con lo designado una relación no más que abstracta, arbitraria (Marler, 1974: 34). Y bien podría considerarse este tipo de uso sígnico (simbólico y natural) el caso de los curiosos habitantes de la biblioteca, de tal modo que en este universo borgeano, los signos lingüísticos del alfabeto romano han pasado a ser elementos estructurales en el constructo de la realidad, y son los elementos constitutivos de la estructura del universo ficcional planteado en la narración, tan naturales, por tanto, en este medioambiente como lo son los libros en una biblioteca.

Pero es cierto que los conceptos de símbolo, en tanto que signo que ostenta una relación convencional con su significado, y de natural, en tanto que expresión fisiológica, parecen casar mal. En La Biblioteca de Babel, la escritura es expresión sígnica cultural: la escritura es producto de un artificio, de la «imitación». Pero, como imitación, lo es de unos elementos significativos («símbolos») que son parte conformante de la estructura del universo («naturales»), de su ser y sus aconteceres.

21 Vale la pena citar explícitamente las palabras, aunque sólo sea por aprovechar la relación que mantienen con el tema tratado: «Ni mi manto oscuro, ni el traje obligado de luto solemne, ni los suspiros vaporosos y profundos, ni el abundante río de lágrimas, ni la expresión abatida del rostro, a más de todas las formas, modos y clases del sufrimiento, pueden descubrir mi estado de ánimo. Todo son cosas que «parecen» en tanto acciones que el hombre interpreta» (Hamlet, I, ii, 78-84). 
En cierto modo, las referencias a la escritura en La Biblioteca de Babel vienen revestidas de un aire mítico, en tanto que se refiere su origen en función de su relación con ciertos objetos esenciales del universo (en tanto que «naturales») y representativos de él (en tanto que «símbolos»). Entonces, la escritura tiene, de hecho, una relación directa, aun en su condición de artificio, con la propia estructura del universo en el que estos personajes se mueven ${ }^{22}$. De esta relación se deriva, entonces, la fiebre bibliófila de los habitantes de este universo: los elementos gráficos contenidos en los libros tienen una relación con la naturaleza del universo: los libros explican el universo de estos personajes.

Esta sería la relación ideal escritura-universo de acuerdo con el concepto «símbolos naturales». Ahora bien: «[los bibliotecarios] sostienen que esa aplicación [de los veinticinco signos] es casual y que los libros nada significan en sí» (F., 92). O sea, que en los veinticinco signos está la representación simbólica del mundo (acaso en esto radique su «naturalidad»), pero, una vez plasmados en el canal comunicativo libro, sucede en numerosos casos que de este principio esencial se deriva un extrañamiento. A pesar de la existencia de numerosas lenguas, la combinación de los veinticinco signos implica en muchos casos un absurdo comunicativo, la incomprensión: «...cuatrocientas diez páginas de inalterable $\mathrm{M} \mathrm{C} \mathrm{V} \mathrm{no} \mathrm{pueden} \mathrm{corresponder} \mathrm{a} \mathrm{ningún}$ idioma, por dialectal o rudimentario que sea» $(F, 93)$. Lo que hace el narrador es reconocer el absurdo. Los bibliotecarios se mueven en un exasperante mundo de combinaciones de signos, las cuales parecen en muchos casos azarosas, sin sentido. Si el mundo se compone de esos textos incomprensibles construidos a partir de una relación directa con los elementos naturales constitutivos del universo, entonces este universo es cognoscitivamente opaco a la mente de los bibliotecarios. $Y$ tiene algo de trágico el hecho de hallarse en un mundo del que apenas se puede saber nada en la mayoría de sus manifestaciones.

El absurdo se traduce también en idiomas imposibles como «un dialecto samoyedo-lituano del guaraní, con inflexiones de árabe clásico» (F, 93). De acuerdo con los principios rectores de la Biblioteca, de la combinación de signos surgiría también la combinación de lenguas. $Y$

22 Esta relación con el universo justifica la idea monogeneticista del lenguaje presente en la narración: aún en la variedad de idiomas y de combinaciones de idiomas $(F, 93)$, permanece el uso de los mismos símbolos gráficos para expresarlos, en virtud de un único origen de la escritura, con una relación directa con los elementos del universo. 
precisamente es en este texto cuya norma es esta extraña combinación idiomática de donde se deduce la norma combinatoria de la Biblioteca, que ya he mencionado. Todo está expuesto en los libros, cuyos textos son la plasmación total del universo (total en un sentido estricto, porque constituye el propio universo). En su calidad de soportes sígnicos, es de suponer que están abiertos a una interpretación, siempre y cuando la combinación de signos en su interior sea comprensible para el lector. Pero lo que es epistemológicamente problemático es que los textos no exponen sólo lo real, sino también lo imaginario, lo falso, lo absurdo, refutaciones verdaderas o falsas de enunciados verdaderos o falsos (F, 94, 99). Hay algo dramático en esta oposición factualidad-ficcionalidad en un mundo donde los libros parecen ser la única fuente de conocimiento posible. Los bibliotecarios parecen seres en busca de verdad o verdades en un mundo cuyos elementos constitutivos: a) no son todos interpretables, b) no todos refieren contenidos veritativos, y c) no son todos aprehensibles en el marco de una existencia finita.

Con estas trabas se van estrechando los horizontes cognoscitivos de los bibliotecarios. Éstos, motivados por un deseo explicativo de su universo, se mueven en una realidad que, de hecho, los sobrepasa. Ante este absurdo, y a partir de sus motivaciones, se desarrolla una creencia (la del narrador) en un libro total que explica el mundo.

¿Qué se espera del libro total? Por lo que se extrae del texto, la idea que se tiene del catálogo es que éste es el fundamento explicativo de la Biblioteca (del universo). Se busca ese libro total porque parece imposible el examen particular de todos los objetos de la Biblioteca para explicar el mundo, de lo cual nace una suerte de fe necesaria: la idea de la existencia de un conjunto sígnico con un valor absoluto o fundamental. En estos términos, La Biblioteca de Babel comparte con La escritura del dios el motivo temático de la búsqueda: un camino intelectivo en pos de un objeto sígnico que es el fundamento del universo de sus personajes. Pero, mientras que en La escritura del dios el objeto estaba dotado de un poder mágico, en esta narración, aunque los bibliotecarios desarrollan una mística y un fervor religioso a su alrededor, la naturaleza del objeto buscado tiene un carácter más bien cognoscitivo: la explicación del mundo. (Nótese que este valor otorgado al objeto se muestra en coherencia con las motivaciones explicativas de los bibliotecarios.)

Pero esta creencia en un libro total encierra sus contradicciones. Para empezar, si de la neutralidad de los signos se deduce que existe 
una exposición total del mundo («el catálogo de catálogos», «el libro total»), pero, por otra parte, se ha producido un extrañamiento, una incomprensión de sentido por la ramificación en idiomas y sus combinaciones, ¿cuál será entonces el criterio idiomático que permita discernir que un libro $\mathrm{X}$ que ha sido encontrado sea el libro total? La naturaleza propia de los bibliotecarios cierra las puertas a todo encuentro con una unidad total de saber absoluto. La búsqueda es, en última instancia, un sinsentido, tanto como lo es, irónicamente, el esfuerzo comunicativo del narrador, ya que todo lo que es posible expresar en signos está ya expresado en alguno de los libros de la casi infinita biblioteca y sin que la comprensión por parte de un receptor esté aún asegurada.

Otra contradicción, más acorde con esta lógica de la totalidad presente en la narración, reside en un factor que el narrador ignora. La Biblioteca es total en principio, pero ocurre que algunos bibliotecarios incurren en una anulación de esta totalidad, bien añadiendo nuevos volúmenes, bien destruyéndolos $(F, 95-96)$. La destrucción de libros causa horror, pero para el bibliotecario los hechos no son tan graves teniendo en cuenta que en alguna parte de la Biblioteca existen, sin duda alguna y de acuerdo con la ley combinatoria que rige ese universo, libros semejantes, con escasas variaciones frente a los que ya han sido destruidos. Ahora bien, no es menos cierto que la destrucción de libros (aunque sea solamente uno) implica necesariamente la negación de la totalidad de la Biblioteca. Y no sólo se niega la totalidad de la biblioteca de acuerdo con las combinaciones de signos, sino que, además, el catálogo ya no es una versión fiel, total, del universo. Cualquier alteración de la totalidad de la biblioteca implica, pues, la falsedad del catálogo.

Por otra parte, el añadido de libros no parece tan nocivo, pero desvela un absurdo. Significa un añadido, la repetición de algo que ya existe, al igual que la propia comunicación del narrador. «Hablar es incurrir en tautologías» $(F, 99)$. Cualquier acto comunicativo escrito altera la norma combinatoria que rige el universo. De acuerdo con esta norma, cualquier añadido incide de forma negativa en la totalidad orgánica de la Biblioteca ${ }^{23}$.

23 Obviamente, no es imposible la repetición artificial, como un acto de voluntad consciente por parte de un bibliotecario, de unas combinaciones sígnicas ya existentes en los libros. Lo que en la narración se señala es su absurdidad de acuerdo con los principios ontológicos, fundamentales de la existencia de este universo, señalados al principio de esta narración. Vid. Nuño (1986: 45-47). 
«(Un número $n$ de lenguajes posibles usa el mismo vocabulario; en algunos, el símbolo biblioteca admite la correcta definición ubicuo y perdurable sistema de galerías hexagonales, pero biblioteca es pan o pirámide o cualquier otra cosa, y las siete palabras que la definen tienen otro valor. Tú, que me lees, ¿estás seguro de entender mi lenguaje?)» $(F, 99)$.

Todo está dicho, ciertamente, pero de la lógica narrativa del cuento no se extrae que ello haya de ser fuente de conocimiento, de saber, de algún tipo de felicidad que el conocimiento pueda brindar, sino la incomprensión y el desconcierto y, en fin, una suerte de absurdo existencial en la propia experiencia vital y cognoscitiva de los bibliotecarios.

De lo visto hasta aquí se pueden extraer algunas generalizaciones que quisiera proponer como aplicables a otras prosas de ficción del autor. En primer lugar, tanto en El espejo de tinta como en La escritura del dios subyacen ciertas ideas sobre la «magia del lenguaje». En segundo lugar, se presenta en algunas narraciones de Borges una visión del mundo como universo sígnico de carácter críptico (es el caso de La escritura del dios y La Biblioteca de Babel).

Paso a comentar primero las ideas sobre la magia del lenguaje. Se ha visto en dos de las narraciones comentadas cómo unos signos con un determinado poder (una potencialidad en sí mismos) actualizan de forma tangible (aparición de imágenes en la tinta, muerte de Yakub) en el universo empírico las virtualidades en ellos contenidas una vez que son pronunciados ${ }^{24}$. El esquema podría ser este:

$$
\text { realización }
$$

$\begin{array}{lll}\text { potencia } \longrightarrow & \text { acto } \\ \text { palabra } & \text { pronunciación } & \text { hecho } \\ \text { causa } & \text { efecto }\end{array}$

24 En el caso de La escritura del dios, lo que se refiere es el efecto esperado de la pronunciación del signo: el cambio de los destinos del mundo. 
Un esquema simple según una visión de tipo aristotélico de los aconteceres en el mundo empírico. Pero es esta la exposición en abstracto de la creencia en la magia del lenguaje.

Obviamente, estas no son creencias atribuibles a Borges. Ahora bien, estas ideas aparecen formuladas en un sentido práctico en el discurso ficcional con bastante coherencia. Dicho de otro modo, la literatura es el campo idóneo donde éstas pueden ser expresadas en tanto que la creencia en una magia del lenguaje bien puede ser trasunto correlativo de la idea de unos poderes de evocación poética existentes en la palabra y que justifican la creación literaria en su vertiente más estética.

La literatura, insisto, es el campo óptimo para que ciertas ideas sobre magia en el lenguaje hallen su expresión porque a estas ideas subyace el mito romántico del poeta como mago, según el cual las palabras ostentan una potencialidad estética y expresiva que sólo unos determinados individuos, los poetas, pueden aprehender y dominar; una vez sometidas estas potencialidades a la técnica del poeta, éstas pueden hallar recepción en el público en general ${ }^{25}$. Tal ideal tan propio de románticos y simbolistas, ese cierto esoterismo en la creación literaria, sigue el mismo esquema que las ideas de la magia del lenguaje. Creo que un examen de la obra literaria de Borges mostraría cómo el autor es bastante proclive, a lo largo de su obra, a seguir esa tendencia a la romantización conceptual del lenguaje (creyese o no su autor en ella), o del mero signo, como es el caso de El espejo de tinta, cuya trama se fundamenta en la brujería, una brujería donde los caracteres sagrados y las figuraciones icónicas son elemento determinante y que ostenta las características de un proceso comunicativo unívoco, dirigido por la voluntad superior del hechicero.

Una concepción semejante de la comunicación sígnica se expresa en La escritura del dios. En este cuento, el sacerdote proyecta en el objeto de la piel del jaguar la noción de que sobre ella se han impuesto los designios de una voluntad subjetiva superior, el dios. No es una consideración banal, teniendo en cuenta la visión cosmológica del sacerdote, que contempla una larga trama causal implícita tras cada concepto que designa a un objeto del mundo sensible. De una manera similar, y

25 La idea, considerada por algunos críticos como pura pose romántica, fue ampliamente explotada por el simbolismo como elemento fundamental de su propia poética. Poemas como Voyelles de Rimbaud o Sur le tombeau d'Edgar Poe de Mallarmé son su aplicación práctica. La determinante influencia posterior del simbolismo explica, a mi entender, la presencia de estas ideas en la literatura occidental del presente siglo, pero la demostración de esto sería ya dominio de un trabajo de literatura comparada. 
a la inversa, en una sola expresión puede haber en potencia el universo entero y todos sus aconteceres. Para el sacerdote, en la piel del jaguar se halla impreso un conjunto críptico, una «sentencia» o enunciado en el que se halla en potencia el universo entero y todos sus posibles aconteceres.

Esta visión concreta del lenguaje con un poder mágico mantiene con el pensamiento cristiano un contacto que ya he señalado. A este conjunto sígnico se le otorga un valor absoluto: el signo mágico es una suerte de identidad abstracta, metafísica, sobrenatural, con todo el universo.

En La Biblioteca de Babel no se presentan consideraciones de ningún tipo sobre magia del lenguaje, pero sí que es palpable el mismo elemento temático que en La escritura del dios: la creencia en un conjunto sígnico de valor absoluto. Se supone que entre todos los conjuntos sígnicos que pueblan el universo hay el libro que es «compendio de todos los demás», que explica a todos los demás libros. Es decir, que encierra en él el sentido del universo. El discurso sobre las falacias y errores que pueda haber tras la creencia del bibliotecario-narrador sería más propio de la lógica o la epistemología. Aquí me he limitado a exponer algunos conceptos de filosofía del lenguaje que justifican las creencias del bibliotecario y que, espero, habrán dado cuenta de la fuerte cohesión conceptual interna que se presenta en esta ficción. Por otro lado, he querido exponer algunas posibilidades lógicas concernientes a la posibilidad de la existencia de ese catálogo, de las cuales espero que habrán dicho algo sobre las creencias y el campo de expectativas del narrador.

De algún modo los personajes de estos dos cuentos, tanto el sacerdote Tzinacán como los bibliotecarios, se encuentran encerrados en un laberinto cognoscitivo, y en ambos cuentos los personajes se crean una expectativa semejante: la creencia en un conjunto sígnico de valor absoluto que puede ser hallado y descifrado, y que les permitirá conjurar su encierro. En qué radica el valor absoluto de cada conjunto sígnico es algo que mantiene una estrecha relación con la naturaleza y las motivaciones de los personajes de cada cuento. En ambos casos parece tratarse del conjuro a la existencia absurda de los personajes. El sacerdote Tzinacán, prisionero y ultrajado, cuyas motivaciones son la voluntad de poder, la venganza y la honra de su dios, busca un signo sagrado cuya existencia viene enunciada por una tradición religiosa. Ese signo es mágico, con un poder de manejo del universo bastante ligado a las motivaciones de Tzinacán. En el caso de La Biblioteca de Babel el valor absoluto del conjunto sígnico buscado no radica tanto 
en el manejo del universo como en su comprensión. Su valor es más bien cognoscitivo, en consonancia con el imperativo epistemológico que parece guiar a los bibliotecarios: una interpretación de los contenidos de los libros que viene a ser, de hecho, la interpretación de un universo entero.

Ambos cuentos se asemejan no sólo en la idea de un conjunto sígnico de valor absoluto, sino en la naturaleza de su búsqueda. Se ha descrito cómo ésta es de carácter analítico, es decir, apriorística, a partir de unas bases epistemológicas sentadas de antemano (la tradición del dios, las leyes de la Biblioteca) que dan las guías sobre la naturaleza y la localización del objeto buscado. En qué medida el método cognoscitivo aplicado ha sido el correcto... En cuanto a La escritura del dios se han planteado algunas posibilidades. En cuanto a La Biblioteca de Babel, las palabras del narrador, a quien cabe suponer ya envejecido después de largas búsquedas, no dejan lugar a dudas: «Hablar es incurrir en tautologías. Esta epístola inútil y palabrera ya existe en uno de los treinta volúmenes de uno de los cinco anaqueles de uno de los incontables hexágonos - y también su refutación» $(\mathrm{F}, 99)$.

\section{Referencias bibliográficas}

ARISTÓTEles (1990). Metafísica [Ed. Trilingüe de V. García Yebra.]. Madrid: Gredos.

BoRGES, J. L. (1939). «La Biblioteca Total». En Sur 59/8, 13-16.

- (1995). «La Biblioteca de Babel». En Ficciones. Madrid: AlianzaEmecé.

- (1995). «Del rigor en la ciencia». En El Hacedor, Madrid: AlianzaEmecé.

- (1996). «La escritura del dios». En Aleph. Madrid: Alianza-Emecé.

- (1997). «El espejo de tinta». En Historia universal de la infamia, Madrid: Alianza-Emecé.

Hierro S. Pescador, J. (1989). Principios de filosofía del lenguaje. Madrid: Alianza.

KANT, I. (1996). Crítica de la razón pura [Ed. Pedro Ribas.]. Madrid: Alfaguara.

LAsswITZ, K. (1958). «The Universal Library». En Fantasia Mathematica, C. Fandiman (ed.). Nueva York: Simon and Schuster.

MARLER, P. (1974). «Animal Communication». En Nonverbal Communication, L. Krames y otros (eds.). Nueva York: Plenum Press. 
SigNOS MÁGICOS Y DE LO ABSOLUTO: APROXIMACIÓN A TÉRMINOS...

NuÑo, J. (1986). La filosofía de Borges. México: FCE.

PéreZ, A. J. (1986). Poética de la prosa de Jorge Luis Borges. Hacia una crítica bakhtiniana de la literatura. Madrid: Gredos.

WitTGensteIn, L. (1995). Tractatus Logico-Philosophicus [Ed. bilingüe J. Muñoz e I. Reguera.]. Madrid: Alianza. 